\title{
Boron Neutron Capture Therapy
}

National Cancer Institute

\section{Source}

National Cancer Institute. Boron Neutron Capture Therapy. NCI Thesaurus. Code

C15378.

A type of radiation therapy in which the patient is given an intravenous boron infusion that is absorbed by tumor cells. Radiation is then directed at the boron, killing the tumor cells but not the surrounding normal tissue. 